\title{
THE INFLUENCE OF SOCIAL DETERMINANTS ON RETIREMENT SAVINGS IN POLAND
}

\author{
DAMIAN WALCZAK, ${ }^{1}$ SYLWIA PIEŃKOWSKA-KAMIENIECKA, ${ }^{2}$ ANNA BERA ${ }^{3}$
}

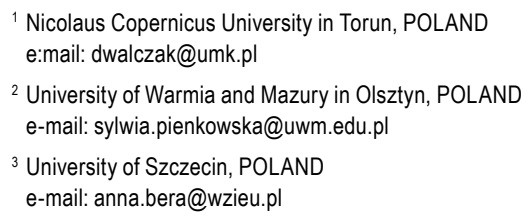

RECEIVED

ACCEPTED

JEL

CLASSIFICATION

KEYWORDS

ABSTRACT
27 November 2017

15 January 2018

D14, E21, H55, J32

social behavior, gender, religiosity, education, savings

Both individuals and entire households save for various reasons. Many factors determine saving for a particular purpose. The article presents social determinants which have an effect on retirement savings. The authors draw on the results of the Social Diagnosis of 2015 - a panel-based study conducted annually by the Council for Social Monitoring since the year 2000. In 2015, the study covered 11,740 households within the whole area of Poland. The study subjects were individuals acting as heads of their households and making key financial decisions concerning the members.

A logistic regression model was used to determine the social and demographic characteristics of household heads who make decisions concerning retirement savings. The results of logistic regression have shown that gender, years of education, religiosity, marital status, whole life satisfaction as well as political and economic views have a significant impact on the decision-making process of saving for old age.

\section{Introduction}

Savings are the part of a household's income which has not been spent on consumption (Białowąs, Olejnik, 2015). They play an important role in the functioning of a household and its members. There are numerous reasons why people decide to save. Savings may be of general nature, i.e. have no particular purpose, or they may be accumulated for a particular purpose. In the latter case, one of the main reasons for saving money is to ensure 
better living standards during retirement, considering that pension benefits paid under the mandatory pension programs have been decreasing substantially (Chybalski, 2016; Jedynak, 2016). Most often, literature references emphasize economic factors which affect saving. According to Cynamon and Fazzari (2017), they include income, owned wealth, level of consumption and household debt. Nonetheless, also of importance, and often decisive, are non-economic factors (van Erp, Vermeer, Vuuren, 2013). While economic and financial factors are significant, they are not sufficient determinants of retirement behavior (van Erp et al., 2013). One of the non-economic aspects, according to Sablosky (2014) and Su et al. (2011), is religiosity which impacts significantly on financial decisions. Gender is also of key importance in the decision-making regarding savings. Women are generally less likely to save extra for retirement than men (Fernández-López, 2015). Differences in saving behavior may also result from the so-called social learning process. Men and women, by observing behaviors of the same socialization agents (e.g. parents, peers) display different attitudes to financial issues (Sereetrakul, Wongveeravuti, Likitapiwad, 2013; Walczak, Pieńkowska-Kamieniecka, 2018). Another key factor affecting saving is also education level and knowledge (Chang, Tang, Liu, 2016; Ellen, Wiener, Fitzgerald, 2012; Lusardi, Mitchell, 2011).

Kapounek, Korab and Deltuvaite (2015) show that financial decisions of households, including those concerning old age savings, are largely influenced by marital status. Consistently married individuals with no record of marital break-up have a significantly higher level of wealth and savings than those divorced or who were not continuously married (Wilmoth, Koso, 2002). In addition, political views are one of social determinants, which have an effect on financial decisions. Individuals with liberal views opt for reducing the role of the State and therefore leaving the majority of decisions, including financial, to the citizens. As a result, in line with their views, they save for old age individually. On the other hand, persons with left-wing views claim that the State should guarantee a certain minimum standard of living to its citizens and, consequently, they save less often (Kollmorgen, 2013). Moreover, people satisfied with their lives make totally different decisions than those that are unsatisfied. Whole life satisfaction is a sum of biological, social, personality and economic conditions and has a multi-faceted dimension. However, current life satisfaction is usually connected with the desire to maintain it on a relatively high standard in the future. This, in turn, is reflected in owning more savings, including savings for old age, which facilitate retention of the status quo standard of living and health in the future (Parr, 2010). As a result, as indicated, saving decisions are determined mainly by the individual traits of each person.

The purpose of this paper is to demonstrate social determinants of retirement savings. It investigates the hypothesis which states that the level of a household's retirement savings is largely affected by the social determinants of its head.

\section{Methodology}

\section{Participants}

The research presented in the article comes from a representative nationwide research the Social Diagnosis conducted in Poland in 2015. In 2015 this study was conducted in 11,740 households within the whole area of Poland (Czapiński, Panek, 2015). The study subject in each household was its head who made key financial decisions concerning all its members. 


\section{Measure}

Dependent variable (owning of old-age savings by household) in the model had a dichotomous character, i.e. zero-one. This variable took on the following form:

$$
Y=\left\{\begin{array}{ll}
1, & \text { in case that the event happened } \\
0, & \text { otherwise }
\end{array} .\right.
$$

The logit model for dichotomous variable $Y$ is determined by the following dependence (Hosmer, Lemeshow, Sturdivant, 2013):

$$
E(Y \mid x)=\pi(x)=\frac{e^{\beta_{0}+\beta_{1} X}}{1+e^{\beta_{0}+\beta_{1} X}} .
$$

The independent variables used in the Model are presented in Table 1.

\begin{tabular}{|c|c|c|}
\hline Variable & Variable description & Nature of the variables \\
\hline Church & On average, how often in a month do you take part in a church service or other religious meetings? & Number \\
\hline Gender & Gender & $\begin{array}{l}0=\text { Women } \\
1=\text { Men }\end{array}$ \\
\hline Education & Years of education & Years \\
\hline Marriage & Do you think marriage is the most important condition of a happy life? & $\begin{array}{l}0=\text { No } \\
1=\text { Yes }\end{array}$ \\
\hline Health & Do you think health is the most important condition of a happy life? & $\begin{array}{l}0=\text { No } \\
1=\text { Yes }\end{array}$ \\
\hline Friends & How many people do you consider as friends? & Number \\
\hline Marital status & Marital status & $\begin{array}{l}1=\text { Single } \\
2=\text { Married } \\
3=\text { Widow } / \text { widower } \\
4=\text { Divorced/separated }\end{array}$ \\
\hline Whole life & How do you evaluate your whole life, could you claim what it was like? & $\begin{array}{l}1=\text { Great } \\
2=\text { Successful } \\
3=\text { Pretty good } \\
4=\text { Neither good nor bad } \\
5=\text { Not successful } \\
6=\text { Unhappy } \\
7=\text { Terrible }\end{array}$ \\
\hline Inequality & We should aim at balancing the incomes of all people & $\begin{array}{l}1=\text { Definitely yes } \\
2=\text { Yes } \\
3=\text { Rather yes } \\
4=\text { Neither yes nor not } \\
5=\text { Rather not } \\
6=\text { No/not } \\
7=\text { Definitely not }\end{array}$ \\
\hline Meaning of life & What, in your opinion, is more important in life? & $\begin{array}{l}0=\text { Pleasures } \\
1=\text { The feeling of purpose }\end{array}$ \\
\hline
\end{tabular}

Table 1. Descriptive statistics for the independent variables

Source: own study based on Social diagnosis (2015). 


\section{Data Analysis}

The analyses of the presented source data on saving, with the use of the IBM SPSS Statistics 24 software, were conducted with the use of the logistic regression model (Hosmer et al., 2013). It allowed the evaluation of the influence of particular traits of the head of the household, presented in Table 1, on the willingness to save for old age by this household.

\section{Results}

As men are more concerned than women about financial issues, they save for old age definitely more frequently (Taft, Hosein, Mehrizi, Roshan, 2013). Consequently, male-headed households are also more willing to save for old age.

Religious people who participate in a church service are more likely to save for old age. Increased participation in a church service of a household head once a month increases the odds of owning savings for old age by $2.2 \%$.

According to other studies (Lusardi, 2016), and non-scientific assumptions, education boosts the willingness to save for old age. Higher education means greater knowledge, including financial competence, regarding the need to save for old age and in effect, as indicated by the research results, an actual decision to save. Every additional year of education that the head of a household has increases viable odds of owning such savings by $2.0 \%$.

Moreover, the number of friends a household head has, has a positive impact on owning savings. Sociable individuals who make friends easily have a greater awareness of the need to save for old age. This results from the so-called social norms. The moment of retirement is a one-time event so it is not possible to rely on one's experience in this matter. Consequently, people observe behaviors of others, family members, friends, how they prepare financially for old age and, above all, how they manage after going into retirement (van Erp et al., 2013). The decision making process considered in the present study is also affected by marital status. Single people take into consideration old age to a small extent whereas married people are more aware of the need to save for old age. Nonetheless, people who are life-experienced and often left alone, i.e. divorced or widowed, save for old age most frequently.

Evidently married people, like divorced and widowed people are more financially literate, which in turn has an effect on financial decisions, including saving for old age (Taft et al., 2013). Moreover Gonzalez and Özcan (2013) claim that the increase in the probability of marital breakup increases the propensity to save by married individuals. Odds of owning savings in households headed by a married person are $8.8 \%$ higher than in those which are singleheaded. Analogically, in households headed by a divorced or separated person these odds are higher by $51.9 \%$, and in widow-headed by as much as $84.3 \%$ when compared to single-headed households.

Individuals who evaluate their life better as well as those who perceive marriage or health as important determinants of a happy life tend to save for old age more often. This can be justified by their desire to own financial resources which will be necessary to lead a happy life or maintain good health which is important to them. On the other hand, it needs to be stressed that people with excellent health need greater financial resources for old age as they have a projected longer time span during which they will be using savings collected during professional activity (Harlow, Brown, 2016). Health status and expectations towards its future condition are therefore significant societal determinants of savings. 
As presented in the research, evaluation of current life also has an effect on owned savings. Odds of savings for old age by individuals who perceive their current life as not successful are $38.6 \%$ lower than among those who perceive their current life as great.

What is more, people who state that incomes of all people should not be balanced save more for retirement. They also claim that incomes should be varied and relate to liberal views which also signal that people should accumulate resources for retirement by themselves. Alternatively, households headed by those who opt for eliminating income inequality save evidently less. Such a view constitutes realization of the socialist ideals and is expressed in reference to the welfare state, i.e. a concept where the State should guarantee, inter alia, suitable pensions (Esping-Andersen, 2013). As a result, such individuals tend to save for old age more often.

Table 2. Estimates of logistic regression model after dropping out insignificant variables for "old-age savings"

\begin{tabular}{|c|c|c|c|c|c|c|c|c|}
\hline \multirow[t]{2}{*}{ Variable } & \multirow[t]{2}{*}{ B } & \multirow[t]{2}{*}{ S.E. } & \multirow[t]{2}{*}{ Wald } & \multirow[t]{2}{*}{ df } & \multirow[t]{2}{*}{ Sig. } & \multirow[t]{2}{*}{$\operatorname{Exp}(B)$} & \multicolumn{2}{|c|}{$\begin{array}{c}95 \% \text { C.I. } \\
\text { for } \operatorname{Exp}(B)\end{array}$} \\
\hline & & & & & & & Lower & Upper \\
\hline Church & 0.022 & 0.009 & 6.004 & 1 & 0.014 & 1.022 & 1.004 & 1.040 \\
\hline Gender & 0.191 & 0.076 & 6.341 & 1 & 0.012 & 1.211 & 1.043 & 1.405 \\
\hline Education & 0.019 & 0.009 & 4.618 & 1 & 0.032 & 1.020 & 1.002 & 1.038 \\
\hline Marriage & 0.268 & 0.065 & 16.771 & 1 & 0.000 & 1.307 & 1.150 & 1.486 \\
\hline Health & 0.129 & 0.063 & 4.217 & 1 & 0.040 & 1.138 & 1.006 & 1.287 \\
\hline Friends & 0.015 & 0.004 & 12.867 & 1 & 0.000 & 1.015 & 1.007 & 1.024 \\
\hline \multicolumn{9}{|c|}{ Marital status } \\
\hline Single & & & 37.180 & 3 & 0.000 & & & \\
\hline Married & 0.084 & 0.111 & 0.581 & 1 & 0.446 & 1.088 & 0.876 & 1.352 \\
\hline Widow/widower & 0.611 & 0.124 & 24.285 & 1 & 0.000 & 1.843 & 1.445 & 2.350 \\
\hline Divorced /separated & 0.418 & 0.146 & 8.234 & 1 & 0.004 & 1.519 & 1.142 & 2.020 \\
\hline \multicolumn{9}{|c|}{ Whole life } \\
\hline Great & & & 14.717 & 6 & 0.023 & & & \\
\hline Successful & -0.103 & 0.146 & 0.495 & 1 & 0.482 & 0.902 & 0.678 & 1.201 \\
\hline Pretty good & -0.286 & 0.150 & 3.671 & 1 & 0.055 & 0.751 & 0.560 & 1.007 \\
\hline Neither good not bad & -0.315 & 0.165 & 3.662 & 1 & 0.056 & 0.730 & 0.528 & 1.008 \\
\hline Not successful & -0.488 & 0.229 & 4.550 & 1 & 0.033 & 0.614 & 0.392 & 0.961 \\
\hline Unhappy & -0.743 & 0.462 & 2.585 & 1 & 0.108 & 0.476 & 0.192 & 1.177 \\
\hline Terrible & -0.144 & 0.956 & 0.023 & 1 & 0.880 & 0.866 & 0.133 & 5.633 \\
\hline \multicolumn{9}{|c|}{ Inequality } \\
\hline Definitely yes & & & 29.186 & 6 & 0.000 & & & \\
\hline Yes & 0.008 & 0.097 & 0.007 & 1 & 0.935 & 1.008 & 0.834 & 1.218 \\
\hline Rather yes & 0.195 & 0.099 & 3.891 & 1 & 0.049 & 1.216 & 1.001 & 1.476 \\
\hline Neither yes nor not & 0.266 & 0.104 & 6.493 & 1 & 0.011 & 1.304 & 1.063 & 1.600 \\
\hline Rather not & 0.286 & 0.118 & 5.904 & 1 & 0.015 & 1.331 & 1.057 & 1.677 \\
\hline No/not & 0.453 & 0.114 & 15.672 & 1 & 0.000 & 1.573 & 1.257 & 1.968 \\
\hline Definitely not & 0.488 & 0.192 & 6.428 & 1 & 0.011 & 1.629 & 1.117 & 2.375 \\
\hline Const. & -1.698 & 0.243 & 48.999 & 1 & 0.000 & 0.183 & & \\
\hline
\end{tabular}

$N=5,957$; Log likelihood = 7,317.726; Nagelkerke's R-squared = 0.031; Cox-Snell's R-squared $=0.022 ;$ Chi-square $(21)=133.755(0.000) ;$ HL test $=7.819(0.451)$.

Source: own study based on Social diagnosis (2015). 


\section{Disculssion}

Analysis of the conducted research results based on a representative Social Diagnosis 2015 study has indicated that social determinants affect saving for old age. Households headed by religious people who engage in religious practices tend to save more for old age. A similar positive impact on saving was observed for education and the number of friends a household head has. Sociable people initiate interpersonal contacts more often and they are undoubtedly open to new knowledge so they have a greater awareness of the need to save for old age.

The level of accumulated savings is also, if not mainly, affected by political-economic views. Households headed by those who support income inequality in society save for old age much more than households who opt for elimination of this inequality. People who see the role of the State in eliminating incomes of its citizens act in line with their views, i.e. they do not save individually for old age as they depend on benefits guaranteed by the State. Such a position is expressed mainly by people with a lower level of education. In fact, it appears that the level of economic knowledge, financial competence and willingness to save increase with the level of education.

Households headed by a single person save for old age much less. Often they do not have many duties and seize the day. As a consequence, saving for old age, or in fact even any saving, is postponed. Bearing that in mind, we may also observe that people who perceive their life as great and health as crucial in life save for old age in order to maintain both these aspects on a satisfactory level on retirement.

As a result, one cannot find any grounds for rejecting the research hypothesis which claims that social determinants have an impact on old-age saving decisions.

\section{Conclusion}

Households save money for various reasons. According to the theory of permanent income (Friedman, 1957), one of the key motives for saving is to accumulate resources in order to compensate for a possible relative decrease of the income after retirement (Niculescu-Aron, Mihăescu, 2012). Saving behavior may be influenced in different ways by various factors. It results from the research presented in this paper that social determinants of households' heads, such as gender, years of education, religiosity, marital status, whole life satisfaction, as well as political and economic views, have a significant impact on the decision-making process of saving for old age in Poland's households.

\section{References}

Ayuub, M.S., Saleem, H.M.N., Latif. M., Aslam, M. (2015). Financial Risk Tolerance Based On Demographic Factors: Pakistani Perspective. International Journal of Information, Business and Management, 7, 226.

Białowąs, S., Olejnik, I. (2015). Oszczędności gospodarstw domowych w różnych fazach cyklu koniunkturalnego. Studia Oeconomica Posnaniensia, 3 (4), 155.

Chang, S., Tang, Y., Liu, Y. (2016). Beyond objective knowledge: The moderating role of field dependence-independence cognition in financial decision making. Social Behavior and Personality: An international journal, 44, 519-528. DOI: 10.2224/ sbp.2016.44.3.519.

Chybalski, F. (ed.) (2016). Adekwatność dochodowa, efektywność i redystrybucja w systemach emerytalnych. Ujęcie teoretyczne, metodyczne i merytoryczne. Warszawa: C.H. Beck.

Cynamon, B.Z., Fazzari, S.M. (2017). Household income, demand, and saving: deriving macro data with micro data concepts. Review of Income and Wealth, 63, 53-69. DOI: 10.1111/roiw.12206.

Czapiński, J., Panek, T. (eds.) (2015). Social diagnosis 2015. Objective and subjective quality of life in Poland, Contemporary Economics. Quarterly of University of Finance and Management in Warsaw, 9, 14-15. DOI: 10.5709/ce.1897-9254.176. 
Ellen, P.S., Wiener, J.L., Fitzgerald, M.P. (2012). Encouraging people to save for their future: Augmenting current efforts with positive visions of the future. Journal of Public Policy \& Marketing, 31, 58-72. DOI: 10.1509/jppm.09.089.

Esping-Andersen, G. (2013). The three worlds of welfare capitalism. Cambridge: John Wiley \& Sons.

Fernández-López, S., Vivel-Búa, M., Otero-González, L. Durán-Santomil, P. (2015). Exploring the gender effect on Europeans' retirement savings. Feminist Economics, 21, 118-150. DOI: 10.1080/13545701.2015.1005653.

Friedman, M. (1957). A Theory of the Consumption Function. Princeton: Princeton University Press.

Gonzalez, L., Özcan, B. (2013). The Risk of Divorce and Household Saving Behavior. Journal of Human Resources, 48, 404-434. DOI: $10.3368 /$ jhr.48.2.404.

Harlow, W.V., Brown, K.C. (2016). Health State and the Savings Required for a Sustainable Retirement. Retrieved from: https://faculty. mccombs.utexas.edu/keith.brown/Research/retirehealth-wp.pdf.

Hosmer, D.W., Lemeshow, S., Sturdivant, R.X. (2013). Applied logistic regression. New Jork: John Wiley \& Sons.

Jedynak, T. (2016). Ryzyko starości a dodatkowy system emerytalny w Polsce. Zeszyty Naukowe, 8 (956), Uniwersytet Ekonomiczny w Krakowie.

Kapounek, S., Korab, P., Deltuvaite, V. (2016). (Ir)rational households' saving behavior? An empirical investigation. Procedia Economics and Finance, 39, 625-633. DOI: 10.1016/S2212-5671(16)30309-4.

Kollmorgen, R. (2013). Theories of postcommunist transformation. Approaches, debates, and problems of theory building in the second decade of research. Studies of Transition States and Societies, 5. Retrieved from: http://www.tlu.ee/stss/wp-content/ uploads/2013/11/kollmorgen.pdf.

Love, D.A. (2010). The effects of marital status and children on savings and portfolio choice. Review of Financial Studies, 23, 385-432. DOI: $10.1093 / \mathrm{rfs} / \mathrm{hhp} 020$.

Lusardi, A., Mitchell, O. (2011). Financial Literacy Around the World: An Overview. NBER Working Paper, 17107. DOI: 10.3386/w17107.

Lusardi, A. (2016). Financial Literacy around the World: Evidence, Theory, and Implications. GFLEC. Retrieved from: http://gflec.org/ wp-content/uploads/2016/09/Presentation-Lusardi-Cambridge-v5.pdf.

Niculescu-Arona, I., Mihăescu, C. (2012). Determinants of Household Savings in EU: What Policies for Increasing Savings? Procedia Social and Behavioral Sciences, 58, 483-492. DOI: 10.1016/j.sbspro.2012.09.1025.

Parr, N. (2010). Satisfaction with life as an antecedent of fertility: Partner + Happiness = Children? Demographic research, 22, 635-662. DOI: 10.4054/DemRes.2010.22.21.

Sablosky, R. (2014). Does religion foster generosity? The Social Science Journal, 51, 545-553. DOI: 10.1016/j.soscij.2014.03.012.

Sereetrakul, W., Wongveeravuti, S., Likitapiwad, T. (2013). Gender differences in saving and spending behaviours of Thai students. Research in Education, 90, 68-82. DOI: 10.7227/RIE.90.1.5.

Social diagnosis (2015). Social diagnosis: database. Retrieved from: http://www.diagnoza.com.

Su, H., Chou, T., Osborne, P. (2011). When financial information meets religion: Charitable-giving behavior in Taiwan. Social Behavior and Personality: An international journal, 39, 1009-1020. DOI: 10.2224/sbp.2011.39.8.1009.

Taft, M.K., Hosein, Z.Z., Mehrizi, S.M.T., Roshan, A. (2013). The relation between financial literacy, financial wellbeing and financial concerns. International Journal of Business and Management, 8, 70. DOI: 10.5539/ijbm.v8n11p63.

Van Erp, F., Vermeer, N., van Vuuren, D. (2013). Non-financial Determinants of Retirement. Netspar Panel Paper, 34. Retrieved from: https://www.cpb.nl/sites/default/files/publicaties/download/cpb-discussion-paper-243-non-financial-determinants-retirement_0. pdf.

Walczak, D., Pieńkowska-Kamieniecka, S. (2018). Gender Differences in Financial Behaviours. Inzinerine Ekonomika-Engineering Economics, 29 (1), 123-132. DOI: 10.5755/j01.ee.29.1.16400.

Wilmoth, J., Koso, G. (2002). Does marital history matter? Marital status and wealth outcomes among preretirement adults. Journal of Marriage and the Family, 64, 254-268.

Cite this article aS: Walczak, D., Pieńkowska-Kamieniecka, S., Bera, A. (2018). The influence of social determinants on retirement savings in Poland. European Journal of Service Management, 1 (25), 319-325. DOI: 10.18276/ejsm.2018.25-39. 